\title{
Revisiting GDP Growth Projections
}

\author{
Fernando M. Martin, Senior Economist
}

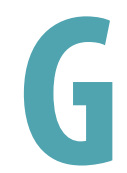

ross domestic product (GDP) contracted significantly during the Great Recession and has grown at a considerably slower pace than its historical average during the subsequent recovery. Both GDP and GDP per capita have diverged noticeably from their prerecession trends: As of 2015:Q4, they are 19 percent and 16 percent below their 1955-2007 trends, respectively. In this essay, I use the most recent data to review the performance of a previous GDP forecast and present new projections up to 2024 .

In a previous essay, I proposed using trends in labor force participation to project GDP for 2014-22. ${ }^{1}$ This projection relied on two main elements: the fact that GDP per labor force participant appeared to be converging back to its pre-Great Recession trend and the high accuracy of Bureau of Labor Statistics (BLS) labor force projections, which are largely based on predictable demographic trends. Since publication of that essay, there have been five new releases of quarterly GDP, updates to previously released data, and a new BLS labor force projection.

Instead of expressing GDP per capita, which corrects for the effects of a growing population, one can divide GDP by the labor force. Doing so accounts for the effects of changing demographics and labor force attachment. Although GDP per labor force participant also contracted severely during the Great Recession, it has nevertheless been converging back to its pre-recession trend. Since 2010, it has grown at an average annual rate of 1.8 percent-higher than its trend annual growth rate of 1.5 percent between 1955 and 2007. The decline in labor force participation rates explains the difference in performance between GDP and GDP per capita on the one hand and GDP per labor force participant on the other. After the labor force participation rate peaked at 67.3 percent in 2000:Q1, it has steadily declined: As of 2015:Q4, it was 62.5 percent. The most recent BLS projections estimate it will reach 60.9 percent in $2024 .^{2}$ This projection is based on estimating that the labor force will grow at an average annual rate of 0.5 percent in the 2014-24 period-considerably slower than the estimated average annual population growth rate of 0.8 percent.

\section{Based largely on predicted trends for labor force participation, GDP is projected to grow at an average annual rate of 2.2 percent over the next decade.}

Assuming that GDP per labor force participant continues to grow at the same rate as it did for the 2010-15 period, I can use the BLS projections for labor force participation to project GDP growth. The figure shows actual and projected real GDP from 2000 to 2024. In addition, it shows these same variables as calculated in November 2014. ${ }^{3}$

The November 2014 projection of GDP for 2015:Q4 overestimated it by 0.9 percent. That is, actual GDP was 0.9 percent lower than expected. However, most of the

\section{Actual and Projected Real GDP}

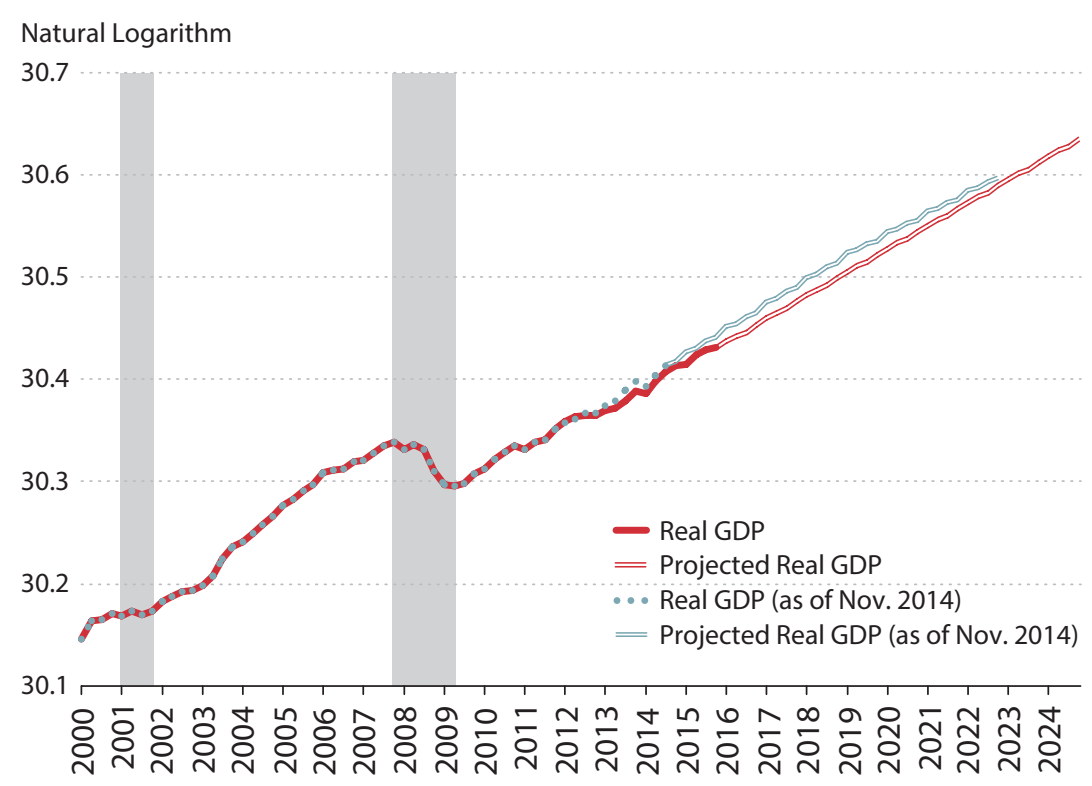

NOTE: The gray bars indicate recessions as determined by the National Bureau of Economic Research.

SOURCE: Bureau of Economic Analysis, Bureau of Labor Statistics, and author's calculations. 
difference can be attributed to revisions in GDP figures:

GDP figures for 2013 and the first three quarters of 2014 were revised downward on average by 0.8 percent and 0.6 percent, respectively. Another part of the difference can be explained by the faster-than-anticipated decline in labor force participation.

Despite these updates, the average annual growth rate of GDP for the next decade remains the same: 2.2 percent. Using the current estimates, the annual growth rate of real GDP is expected to converge to 2.3 percent by 2024 . Note that this rate is somewhat higher than the annual growth projected by the Congressional Budget Office for potential GDP, which is expected to converge toward 2.0 percent over the next decade. 4 The current projections also predict a widening of the (negative) gap between real GDP and its prerecession trend: from 19 percent in 2015:Q4 to 26 percent in 2024:Q4.

\section{Notes}

1 See Martin (2014).

2 See Toossi (2015) for a description and analysis of the most recent labor force projections.

3 Note that the previous essay showed figures with GDP per capita but described the calculations for GDP and presented results for GDP growth. The GDP series displayed in the current figure simply multiplies the GDP per capita series of the previous essay by the total population, as measured in November 2014.

${ }^{4}$ See Congressional Budget Office. "The Budget and Economic Outlook: 2015 to 2025." January 26, 2015; https://www.cbo.gov/publication/49892.

\section{References}

Martin, Fernando M. "Projecting GDP Growth Using Trends in Labor Force Participation." Federal Reserve Bank of St. Louis Economic Synopses, No. 26, November 24, 2014; https://research.stlouisfed.org/publications/economicsynopses/2014/11/24/projecting-gdp-growth-using-trends-in-labor-forceparticipation/.

Toossi, Mitra. "Labor Force Projections to 2024: The Labor Force Is Growing, but Slowly." Bureau of Labor Statistics, Monthly Labor Review, December 2015; http://www.bls.gov/opub/mlr/2015/article/labor-force-projections-to2024.htm. 